Published in final edited form as:

Methods Mol Biol. 2014 ; 1133: 141-154. doi:10.1007/978-1-4939-0357-3_9.

\title{
Caspase Protocols in Mice
}

\author{
Varsha Kaushal, \\ Biology Department, Hendrix College, 1600 Washington Avenue, Conway, AR, USA \\ Christian Herzog, \\ Department of Internal Medicine, University of Arkansas for Medical Sciences, 4301 West \\ Markham Street, Slot 501, Little Rock, AR, USA
}

Randy S. Haun, and Central Arkansas Veterans Healthcare System, 4300 West 7th Street, 111D, Little Rock, AR, USA. Department of Pharmaceutical Sciences, University of Arkansas for Medical Sciences, 4301 West Markham Street, Slot 753, Little Rock, AR, USA

\section{Gur P. Kaushal}

Department of Internal Medicine, University of Arkansas for Medical Sciences, 4301 West Markham Street, Slot 501, Little Rock, AR, USA. Central Arkansas Veterans Healthcare System, 4300 West 7th Street, 111D, Little Rock, AR, USA

\begin{abstract}
Members of the caspase family of proteases are evolutionarily conserved cysteine proteases that play a crucial role as the central executioners of the apoptotic pathway. Since the discovery of caspases, many methods have been developed to detect their activation and are widely used in basic and clinical studies. In a mouse tissue, caspase activation can be monitored by cleavage of caspase-specific synthetic substrates and by detecting cleaved caspase by western blot analysis of the tissue extract. In tissue sections, active caspase can be detected by immunostaining using specific antibodies to the active caspase. In addition, among the myriads of caspase-specific substrates known so far, cleaved fragments produced by caspases from the substrates such as PARP, lamin A, and cytokeratin-18 can be monitored in tissue sections by immunostaining as well as western blots of tissue extracts. In general, more than one method should be used to ascertain detection of activation of caspases in a mouse tissue.
\end{abstract}

\section{Keywords}

Caspases; Immunoblot; Immunostaining; Antibodies; Tetrapeptide substrates; Chromophore; Homogenization; Deparaffinization

\section{Introduction}

Members of the caspase family of proteases are evolutionarily conserved cysteine proteases that play a crucial role as the central executioners of the apoptotic pathway. In addition to 
their apoptotic role in embryogenesis and maintaining cellular homeostasis, caspases play non-apoptotic roles in inflammation, cell differentiation, proliferation, motility, and neuronal functions including neural axon pruning and synapse elimination [1-3]. However, most of the characteristic biochemical and morphological features occurring in apoptotic cells that were originally observed by Kerr et al. [4] are generally attributed to the action of caspases on the specific cellular substrates [5-8].

Since the discovery of caspases in the 1990s many methods designed to detect activation of caspases have been developed and are widely used in basic and clinical studies. These methods include (1) determination of caspase activity using specific synthetic substrates designed to contain fluorogenic or chromogenic leaving groups after the aspartate residue; (2) detection of the specific active caspase by western blot using an antibody specific to active caspase; (3) detection of caspase-specific cleaved products of PARP, cytokeratin-18, and lamin A by western blot; (4) immunocyto-chemical localization of an activated caspase (cleaved caspase) using antibodies specific for active (cleaved) caspase; (5) detection of active caspases by use of fluorochrome-labeled inhibitors of $c a$ spases (FLICA) as affinity ligands that bind to the active center of the active caspase [9]; and (6) use of tandem molecules of green-, blue-, cyan-, or yellow-fluorescent protein covalently linked to a small peptide that target a caspase [10]. These methods are routinely and widely used in in vitro cell culture studies. However, only some of these methods can be successfully used to detect caspase activation in in vivo situations. This chapter provides details of the following methods that can be used to determine caspase activation in a mouse tissue: (1) caspase enzyme assay in mouse tissue homogenates using synthetic peptide substrates, (2) detection of cleaved caspases in mouse tissue homogenates by western blot analysis, (3) immunostaining of caspases in tissue sections with antibodies specific to full-length and cleaved (active) caspases, and (4) detection of caspase-specific cleaved products of poly (ADP- ribose) polymerase (PARP), cytokeratin-18, and lamin A in tissue homogenates and tissue sections as a measure of caspase activation.

\section{Materials}

All animal protocols should be approved and conducted in accordance with the Institutional Animal Care and Use Committee.

\subsection{Caspase Enzyme Assay in Mouse Tissue Homogenates Using Synthetic Peptide Substrates}

1. Lysis buffer for mouse tissues: $50 \mathrm{mM}$ HEPES, $\mathrm{pH}$ 7.5, $0.1 \%$ CHAPS, $2 \mathrm{mM}$ dithiothreitol, $0.1 \%$ Nonidet P-40, 1 mM EDTA, 1 mM phenylmethylsulfonyl fluoride, $2 \mu \mathrm{g} / \mathrm{ml}$ leu-peptin, and $2 \mu \mathrm{g} / \mathrm{ml}$ pepstatin A at $4{ }^{\circ} \mathrm{C}$.

2. Thermo Scientific Pierce BCA (bicinchoninic acid) Protein Assay Kit.

3. Caspase assay buffer: $100 \mathrm{mM}$ HEPES, $\mathrm{pH} 7.2,10 \%$ sucrose, $0.1 \%$ CHAPS, 1 $\mathrm{mM}$ Na-EDTA, and $2 \mathrm{mM}$ dithiothreitol.

4. Stock solution for caspase substrate: $20 \mathrm{mM}$ caspase peptide substrates in dimethyl sulfoxide (DMSO). DEVD-AMC or DEVD -AFC for caspase-3/7, VEID-AMC or 
VEID-AFC for caspase-6, YVAD-AMC or YVAD-AFC for caspase-1, VDVADAMC or VDVAD-AFC for caspase-2, LEHD-AMC for cas-pase-9, and IETDAMC or IETD-AFC for caspase-8.

5. Dounce homogenizer.

6. Microplate reader (Molecular Devices, SpectraMaxM5 or equivalent).

\subsection{Detection of Cleaved Caspases in Mouse Tissue Homogenates by Western Blot Analysis}

1. Lysis buffer: $50 \mathrm{mM}$ HEPES, pH 7.5, $0.1 \%$ CHAPS, $2 \mathrm{mM}$ dithiothreitol, $0.1 \%$ Nonidet P-40, 1 mM EDTA, $1 \mathrm{mM}$ phenylmethylsulfonyl fluoride, $2 \mu \mathrm{g} / \mathrm{ml}$ leupeptin, and $2 \mu \mathrm{g} / \mathrm{ml}$ pepstatin A at $4{ }^{\circ} \mathrm{C}$.

2. Thermo Scientific Pierce BCA Protein Assay Kit.

3. Dounce homogenizer.

4. MiniProtean II (Bio-Rad) protein gel apparatus.

5. TEMED.

6. Solution A: $30 \%$ acrylamide, $0.8 \%$ bisacrylamide ( $75 \mathrm{~g}$ acrylamide and $2 \mathrm{~g} N, N$ methylene-bisacrylamide in $250 \mathrm{ml}$ distilled water).

7. Solution B: $1.5 \mathrm{M}$ Tris- $\mathrm{HCl}, \mathrm{pH}$ 8.8. Dissolve $45.5 \mathrm{~g}$ Tris in $200 \mathrm{ml}$ distilled water. Adjust $\mathrm{pH}$ with $\mathrm{HCl}$ to $\mathrm{pH} 8.8$. Add distilled water to $250 \mathrm{ml}$.

8. Solution C: $0.5 \mathrm{M}$ Tris-HCl, $\mathrm{pH}$ 6.8. Dissolve $15.1 \mathrm{~g}$ Tris in $200 \mathrm{ml}$ distilled water. Adjust $\mathrm{pH}$ with $\mathrm{HCl}$ to 6.8. Add distilled water to $250 \mathrm{ml}$.

9. Solution D: $10 \%$ SDS.

10. Solution E: $10 \%$ (w/v) ammonium persulfate (APS; add $100 \mathrm{mg}$ in $1 \mathrm{ml}$ of distilled water, prepare at the time of gel casting).

11. $2 \times$ SDS-sample buffer: $0.76 \mathrm{~g}$ Tris, $10 \mathrm{ml}$ of glycerol, $5 \mathrm{ml}$ of 2-mercaptoethanol, 2 $\mathrm{mg}$ bromophenol-blue, $5 \mathrm{~g}$ SDS. Add distilled water to make $100 \mathrm{ml}$ and adjust $\mathrm{pH}$ to 6.8 with $1 \mathrm{~N} \mathrm{HCl}$.

12. $10 \times$ SDS-running buffer: $60 \mathrm{~g}$ Tris, $288 \mathrm{~g}$ glycine, $20 \mathrm{~g}$ SDS in $2 \mathrm{~L}$ of distilled water. Adjust $\mathrm{pH}$ to 8.3 .

13. $10 \times$ transfer buffer: $30 \mathrm{~g}$ Tris, $144 \mathrm{~g}$ glycine in $20 \% \mathrm{MeOH}$ to $1 \mathrm{~L}$.

14. PVDF membrane.

15. $10 \times$ PBS: $160 \mathrm{~g} \mathrm{NaCl}, 4 \mathrm{~g} \mathrm{KCl}, 28.8 \mathrm{~g} \mathrm{Na}_{2} \mathrm{HPO}_{4}, 4.8 \mathrm{~g} \mathrm{KH}_{2} \mathrm{PO}_{4}$. Add distilled water to $2 \mathrm{~L}$.

16. PBS-Tween-20 buffer ( $1 \times$ PBS-T): $1 \times$ PBS, $0.05 \%$ Tween- 20 .

17. Dry milk.

18. $1 \mathrm{M}$ DTT stock solution in distilled water stored at $-20{ }^{\circ} \mathrm{C}$. 
19. Primary antibodies to procaspases and cleaved (active) caspases (e.g., from Cell Signaling Technology Inc.).

20. Anti-GAPDH antibody (e.g., sc-47724, Santa Cruz Biotechnology).

21. Appropriate HRP-conjugated secondary antibodies.

22. Chemiluminescence reagent (e.g., Super Signal WestPico Chemiluminescence Reagent from Thermo Scientific).

23. Stripping solution for western blot membranes: $62.5 \mathrm{mM}$ Tris-HCl, $\mathrm{pH} 6.7,2 \%$ SDS, and $100 \mathrm{mM}$ 2-mercaptoethanol (should be added just before use).

24. Gel imaging system (optional; e.g., Bio-Rad Chemidoc- System).

\subsection{Detection of Caspases by Immunostaining with Antibodies Specific to Full-Length and Cleaved (Active) Caspases}

1. Tissue fixative: $10 \%$ neutral-buffered formalin (e.g., Sigma HT501128).

2. Paraffin: Use paraffin heated to $56-58^{\circ} \mathrm{C}$.

3. PBS-T: $1 \times$ phosphate-buffered saline, $\mathrm{pH} 7.4,0.05 \%$ Tween-20.

4. Graded ethanol and xylene: 70, 80, 95, and $100 \%$ ethanol and xylene.

5. Antigen retrieval buffer: $10 \mathrm{mM}$ sodium citrate $\mathrm{pH} 6.0,0.05 \%$ Tween-20.

6. $1 \% \mathrm{H}_{2} \mathrm{O}_{2}$ in PBS containing $0.1 \%$ sodium azide.

7. Blocking buffer: $5 \%$ BSA in PBS-T with up to $0.1 \%$ Triton X-100 as needed.

8. Appropriate primary and secondary antibodies.

9. Antibody dilution buffer: $5 \%$ BSA in PBS-T.

10. HRP substrate solution: $0.2 \mathrm{mg} / \mathrm{ml} 3,3^{\prime}$-diaminobenzidine (DAB) tetrahydrochloride, $0.012 \% \mathrm{H}_{2} \mathrm{O}_{2}, 20 \mathrm{mM}$ citric acid monohydrate, $100 \mathrm{mM}$ imidazole, $100 \mathrm{mM} \mathrm{NaCl}$, pH 7.0.

11. $4^{\prime}, 6^{\prime}$-Diamidino-2-phenylindole (DAPI).

12. Eukitt mounting medium (Electron Microscopy Sciences) or other permanent mounting medium.

13. VECTASHIELD mounting medium.

14. Tissue processor, optional (e.g., Tissue Tek VIP E300 Tissue Processor from Sakura).

15. Rotary microtome (e.g., Microm HM325).

16. Slide warmer. 


\subsection{Detection of Caspase-Specific Cleaved Products of PARP, Cytokeratin-18, and Lamin A in Tissue Homogenates and Tissue Sections as a Measure of Caspase Activation}

1. All reagents described in Subheading 2.2 (except for caspase antibodies) for western blot analysis and Subheading 2.3 for immunodetection.

2. Antibodies: PARP antibodies (e.g., from Cell Signaling Technology Inc.), antiM30 CytoDEATH (cytokeratin-18 epitope) monoclonal antibody from Roche Applied Science, and antibody to cleaved lamin A (small subunit, e.g., from Cell Signaling Inc.). Cleaved lamin A antibody detects the fragments of lamin A/C resulting from cleavage at aspartic acid 230 by active caspase. It does not react with mature lamin A/C protein.

\section{Methods}

\subsection{Caspase Enzyme Activity Assay in Mouse Tissue Homogenate Using Synthetic Peptide Substrates}

Proteins susceptible to caspase cleavage possess a tetrapeptide recognition sequence containing the scissile $\mathrm{P} 1$ aspartate residue at its $\mathrm{C}$-terminus. These proteins are recognized by the caspases and are cleaved following the essential aspartic acid residue. Thornberry et al. [11] applied a positional scanning synthetic combinatorial library approach with the tetrapeptide recognition sequence containing a 7-amino-4-methylcoumarin (AMC) fluorochrome (Ac-X-X-X-Asp-AMC) and determined cleavage specificities of different caspases in vitro. Based on the specific cleavage sites of various caspases, synthetic small peptide substrates containing a chromo-phore after the aspartate group have been synthesized that are commercially available (e.g., Peptide International Inc., Louisville, Kentucky; Bachem AG, Bubendorf, Switzerland) and are commonly used as synthetic substrates to determine the caspase activity. The peptides YVAD, VDVAD, DEVD, VEID, IETD, and LEHD are considered to be specific for caspase-1, -2, -3, -6, -8, and -9, respectively (see Note 1). The peptides are conjugated to AMC (detected by excitation at $380 \mathrm{~nm}$ and emission at $460 \mathrm{~nm}$ ) or 7-amino-4-trifluoromethylcoumarin (AFC; detected by excitation at $405 \mathrm{~nm}$ and emission at $500 \mathrm{~nm}$ ), or to the chromophore, $p$-nitroanilide (pNA: detected colorimetrically by absorbance at $400 \mathrm{~nm}$ ). Upon cleavage by a specific caspase, the liberated fluoro-chrome or chromophore is detected by a fluorometer or spectrophotometer, respectively. Caspase activation using synthetic substrates has been previously determined in diabetic mouse liver [12], renal ischemia-reperfusion injury [13], cerebral ischemia [14], and lungs during renal ischemia [15]. Thus, the activity of caspases in crude homogenates of tissues can be determined using the synthetic substrates (see Note 2).

\footnotetext{
${ }^{1}$ Caspase specificity for the synthetic short peptide substrates is highly promiscuous such that there is overlapping cleavage specificity for these short peptide synthetic substrates. It was reported that compared to other caspases, caspase-3 was more efficient to cleave most of the peptide substrates [36]. Also, DEVD, a commonly used caspase-3 substrate, is also cleaved by other caspases including caspase- $2,-6,-7,-8$, and $-10[27,36]$.

2 In addition to the caspases, animal tissue homogenates also contain endogenous X chromosome-linked inhibitors of apoptosis (xIAPs) that can inhibit caspase- $3,-7$, and -9 activity [37].
} 


\subsubsection{Preparation of Tissue Homogenate}

1. Harvest mouse tissue and homogenize using a Dounce homogenizer in lysis buffer. Mouse tissue can be stored and kept in $-80^{\circ}$ freezer for future use.

2. Centrifuge the homogenate at $10,000 \times g$ for $10 \mathrm{~min}$ to obtain the supernatant.

\subsubsection{Determination of Protein Concentration in Tissue Homogenate (See Note 3)}

1. Using serial dilutions, prepare six standards with bovine serum albumin (BSA) concentrations ranging from 2 to $0.0625 \mathrm{mg} / \mathrm{ml}$.

2. In a 96-well microplate, add in triplicates $25 \mu \mathrm{l}$ of standards, blank (distilled water), and diluted tissue sample (1:20).

3. Prepare BCA reagent: Add BCA reagent $\mathrm{A}$ to reagent $\mathrm{B}$ in a ratio of 50 to 1 .

4. Add $200 \mu \mathrm{l}$ of the BCA reagent mixture to $25 \mu \mathrm{l}$ of standard, sample, and blank in a microplate.

5. Mix well while avoiding bubbles and incubate the plate at $37^{\circ} \mathrm{C}$ for $30 \mathrm{~min}$ and read the absorbance at $562 \mathrm{~nm}$ using a spectrophotometer plate reader. Using the standard curve constructed with the standards and blank, determine the protein concentrations of the tissue homogenates.

\subsubsection{Caspase Activity Measurement}

1. Transfer equal amounts of tissue homogenate protein $(10-50 \mu \mathrm{g})$ to each well of a 96-well microplate containing $100 \mu \mathrm{l}$ of caspase buffer with $50 \mu \mathrm{M}$ of the fluorogenic substrate.

2. Incubate the reaction mixture in microplate for $1 \mathrm{~h}$ at $37^{\circ} \mathrm{C}$.

3. Determine the amount of liberated fluorescent group. To detect AMC use an excitation wavelength of $380 \mathrm{~nm}$ and an emission wavelength of $460 \mathrm{~nm}$. AMC is used as a standard. Based on the standard curve made from a fluorescence reading with free AMC, the data for caspase activity are expressed as nanomoles of liberated AMC (see Note 4). If the caspase substrate coupled to the fluorescent group AFC is used for the assay, the same protocol is used as described for the AMC-conjugated substrate, except that the liberated AFC should be determined with an excitation wavelength of $405 \mathrm{~nm}$ and an emission wavelength of $500 \mathrm{~nm}$. If the caspase substrate is conjugated to the chromophore pNA, the same protocol for the assay is used except that the liberated pNA should be quantified using a spectrophotometer microplate reader at an absorbance of $400 \mathrm{~nm}$. The concentration of tetrapeptide with pNA is generally $0.2 \mathrm{mM}$ to ensure estimation of activity within a linear range of substrate utilization.

\footnotetext{
${ }^{3}$ Usually, $10-20 \mathrm{mg}$ mouse tissue in $0.5 \mathrm{ml}$ of lysis buffer will yield $8-10 \mathrm{mg} / \mathrm{ml}$ protein.

${ }^{4}$ To ensure appropriate estimation of caspase activity, time- dependence and dose-response of the substrate concentration should be examined. The time of incubation and the amount of substrate concentration should be used for the assay within the linear range.
} 


\subsection{Detection of Cleaved Caspases in Mouse Tissue Homogenates by Western Blot Analysis}

Caspases are synthesized in the cytosol as inactive proenzymes containing a prodomain, a large subunit ( $20 \mathrm{kDa})$, and a small subunit $(\sim 10 \mathrm{kDa})$. This method is based on the principal that procaspases are proteolytically processed to large and small subunits to become active enzymes and detecting these subunits by western blots. In response to an apoptotic stimulus, the initiator or apical caspases, caspase- $8,-10$, or -9 , are activated and proteolytically process the effector caspases, caspase- $3,-6$, and -7 into large and small subunits that reassociate to become active heterodimers. In their latent inactive conformation, the effector caspases are dimeric whereas the initiator caspases are monomeric. The initiator caspases become dimers on activation by forming scaffolding oligomeric complexes via interaction with the adapter molecules. For example, caspase- 8 is activated by forming DISC as the oligomeric complex and caspase- 9 is activated by forming "apoptosome" as an oligomeric platform (see Note 5). The pro-caspase and the processed fragments can be detected by western blot analysis using specific antibodies that detect epitopes in pro-caspase and/or the cleaved fragments. The assay of cleaved (active) caspases has been previously performed in mouse tissues in cerebral ischemia [14], focal cerebral ischemia [16], lungs during renal ischemia [15], cardiac ischemia-reperfusion injury [17], and renal ischemia reperfusion injury [18] (see Notes 6 and ${ }^{7}$ ).

3.2.1 Preparation of Tissue Homogenate-Follow protocol described in Subheading 3.1.1.

3.2.2 Determination of Protein Concentration in Tissue Homogenate-Follow protocol described in Subheading 3.1.2.

\subsubsection{Sodium Dodecyl Sulfate-Polyacrylamide Gel Electrophoresis}

1. Assemble a MiniProtean II (Bio-Rad) protein gel apparatus according to the manufacturer's instructions. Use clean glass plates. Rinse plates with distilled water and ethanol. After assembly, ensure that there is no leakage.

2. Prepare $12 \%$ separating gel: Mix $8 \mathrm{ml}$ of solution A with $6.7 \mathrm{ml}$ of distilled water and $5 \mathrm{ml}$ of solution B in a small flask and degas briefly. Add $200 \mu \mathrm{l}$ of solution D, then $100 \mu \mathrm{l}$ of solution E and $10 \mu \mathrm{l}$ TEMED, and mix. This will start the polymerization. Quickly pour the solution into the gel assemblies and overlay each gel with $0.2 \mathrm{ml}$ of a $50 \%$ methanol/water mixture. Let the separating gel polymerize for $30 \mathrm{~min}$.

3. Remove the overlay before pouring stacking gel. Prepare $4 \%$ stacking gel: Mix 1.3 $\mathrm{ml}$ of solution A with $6.1 \mathrm{ml}$ of distilled water and $2.5 \mathrm{ml}$ of solution $\mathrm{C}$ and degas

\footnotetext{
${ }^{5}$ Cleavage of initiator caspases is not necessary for their activation. The detection of proteolytic fragments due to internal proteolysis of these caspases may therefore, not represent true activation of the initiator caspases. Caspase- 8 and -9 may be active without being cleaved or without altered mobility on western blots. Thus, additional methods including enzymatic activity assay should be performed.

${ }^{6}$ Caspase-cleaved products in a mouse tissue may not remain stable and may become targets of other proteases for further proteolysis. Therefore, the level of cleaved product sometimes may not reflect true caspase activity.

${ }^{7}$ The method relies on the source and availability of high quality antibodies for the pro-form and cleaved form of caspases.
} 
briefly. Add $100 \mu \mathrm{l}$ of solution $\mathrm{D}, 50 \mu \mathrm{l}$ of solution E, and $10 \mu \mathrm{l}$ TEMED, mix, and pour on top of separating gel, insert comb, and let polymerize for $30 \mathrm{~min}$.

4. Sample preparation and gel run: Mix $50 \mu \mathrm{g}$ aliquots of tissue homogenate with 1 volume of $2 \times$ SDS-sample buffer and boil for $5 \mathrm{~min}$ at $95-100{ }^{\circ} \mathrm{C}$. Spin briefly and load the samples on SDS gel. Run gels at $200 \mathrm{~V}$ (constant voltage) for $45 \mathrm{~min}$.

5. Transfer proteins onto PVDF membrane (wet-transfer apparatus from Bio-Rad): Prepare a $1 \times$ transfer buffer containing $20 \%$ methanol and precool at $4{ }^{\circ} \mathrm{C}$ before use. Assemble gel sandwich according to the manufacturer's instruction and run transfer at $100 \mathrm{~V}$ for $1 \mathrm{~h}$.

6. Disassemble gel sandwich and wash the blot briefly in $1 \times$ PBS-T and mark the orientation of the gel. Block in $5 \%$ dry milk in PBS-T at room temperature on a shaking platform for $1 \mathrm{~h}$.

7. Incubate the blot with primary antibody diluted $1: 1,000$ in $1 \times \mathrm{PBS}-\mathrm{T}$ at $4{ }^{\circ} \mathrm{C}$ overnight.

8. Wash the blot with $1 \times$ PBS-T $4 \times 5$ min each

9. Incubate with secondary antibody (e.g., goat anti-rabbit HRP-conjugated $\operatorname{IgG}$; Santa Cruz cat\# sc-2004) diluted 1:10,000 in $1 \times$ PBS-T at room temperature for 1 h.

10. Wash the blot with $1 \times$ PBS-T $4 \times 5$ min each.

11. Develop the blot with a chemiluminescence reagent and record the signal by exposing autoradiography films or record digitally.

\subsubsection{Reprobing Western Blots for Loading Control}

1. Wash membranes briefly in distilled water and incubate in $50 \mathrm{ml}$ of stripping solution in a water bath shaker at $50{ }^{\circ} \mathrm{C}$ for $30 \mathrm{~min}$.

2. Remove stripping solution by washing with several rinses of distilled water.

3. Equilibrate the blots in $1 \times$ PBS-T and perform blocking as described in Subheading 3.2.3 (step 6). Incubate with anti- GAPDH antibody diluted in $5 \%$ dry milk in PBS-T at $1: 500$ at $4{ }^{\circ} \mathrm{C}$, overnight.

4. Wash the blot with $1 \times$ PBS-T $4 \times 5$ min each.

5. Incubate with secondary antibody diluted in $1 \times \mathrm{PBS}-\mathrm{T}$ at room temperature for $1 \mathrm{~h}$.

6. Wash the blot with $1 \times$ PBS-T $4 \times 5$ min each.

7. Develop the blot with a chemiluminescence reagent and record the signal by exposing autoradiography films or record digitally.

\subsection{Immuno-detection of Caspases in Tissue Sections with Antibodies Specific to Full- Length and Cleaved (Active) Caspases}

Immunostaining can be used to detect both active and procaspases in tissue section using specific antibodies. Both fluorescent- and nonfluorescent-based methods for 
immunohistological detection can be used in tissue sections. In the fluorescent-based technique, the primary antibody to a specific antigen (active caspase) is first allowed to bind to the antigen in a tissue section and then the secondary antibody carrying the fluorophore is used to bind to the primary antibody. The fluorophore bound to the primary antibody is visualized using a fluorescent microscope. In the nonfluorescent based method, a histochemical technique known as immunoperoxidase labeling is commonly used. In this technique, the primary antibody first binds to corresponding antigen in the tissue section and then a secondary antibody conjugated with peroxidase enzyme is introduced that binds to the primary antibody. Treatment with a horseradish peroxidase (HRP) substrate solution (e.g., $3,3^{\prime}$-diami-nobenzidine (DAB) tetrahydrochloride solution) results in brown stain which is visualized under a light microscope. Immunolocalization of active caspases is a commonly used technique to detect active caspases in a variety of mouse organs. For example, immunostaining with active caspase- 3 in mouse tissue sections has been used to identify apoptotic cells [19-21]. The immunofluorescence technique has been used in brain tissue [22], liver injury [23], ischemic brain [24], a controlled cortical impact (CCI) model [25], and conjunctival epithelia in B6 mice [26]. The availability of specific antibodies to active caspase has helped in the detection of active caspase in paraffin-embedded, formalin-fixed mouse tissues.

\subsubsection{Preparation of Tissue Sections}

1. Cut mouse tissue appropriately from an organ of study and quickly immerse in a fixative buffer for $12 \mathrm{~h}$ to 2 days (see Note 8).

2. Paraffin-Embedding: Most histology labs use a tissue processor to initially process the fixed tissue for paraffin embedding. However, the procedure described in the following steps can be used.

3. Remove fixative buffer from the tissue and dehydrate the tissue specimen in a series of graded ethanol treatments starting with $70 \%$, proceeding through 80 , 95 $100 \%$ ethanol.

4. Remove ethanol and add xylene for $15 \mathrm{~min}$.

5. Following the removal of xylene, add paraffin that has been heated to about $57^{\circ} \mathrm{C}$, leave for 10-30 $\mathrm{min}$ at this temperature, and then remove paraffin as much as possible. Again treat the tissue specimen with new paraffin at about $57^{\circ} \mathrm{C}$ for 10 $30 \mathrm{~min}$ and remove the unbound paraffin. Repeat this step two more times.

6. Keep the paraffin block specimens for at least $1 \mathrm{~h}$ at room temperature and then store under refrigeration until used for making sections.

7. Cut sections at $5-10 \mu \mathrm{m}$ thickness on a rotary microtome and then dry on a slide warmer prior to the staining process.

\subsubsection{Deparaffinization and Antigen Retrieval}

1. Immerse the sections in xylene for $5 \mathrm{~min}$, repeat once.

\footnotetext{
${ }^{8}$ Leaving samples longer than 3 days in fixative (over-fixation) should be avoided as it can lead to uneven and weak staining.
} 
2. Remove xylene and incubate in $100 \%$ ethanol for $3 \mathrm{~min}$, repeat one more time and then incubate in $95 \%$ followed by $80 \%$ ethanol for 1 min each.

3. After removing ethanol, rinse with double-distilled water.

4. Transfer slides into a glass jar filled with antigen retrieval buffer and microwave until solution starts boiling (e.g., heat three times for $20 \mathrm{~s}$ each) (see Note 9).

5. Let glass jar cool to room temperature ( $20 \mathrm{~min})$.

6. Wash the sections in PBS-T for $5 \mathrm{~min}$, repeat two times.

\subsubsection{Staining Procedure}

\subsubsection{Immunohistochezmical Staining}

1. Incubate the deparaffinized sections in $1 \% \mathrm{H}_{2} \mathrm{O}_{2}$ in PBS containing $0.1 \%$ sodium azide for $10 \mathrm{~min}$. The endogenous peroxidase activity is quenched by incubation with $\mathrm{H}_{2} \mathrm{O}_{2}$.

2. Incubate the sections in blocking buffer at room temperature for $30 \mathrm{~min}$ (see Note $10)$.

3. Incubate the sections with caspase antibody at appropriate dilution (at least 1:200) in antibody dilution buffer in a humidified chamber for $1 \mathrm{~h}$ at room temperature or overnight at $4{ }^{\circ} \mathrm{C}$. To assess nonspecific staining or verify the binding specificities of primary antibodies, incubate the sections in antibody dilution buffer or equal amounts of nonspecific mouse, rabbit, or goat immunoglobulins without the primary antibody for negative controls.

4. Wash the sections with PBS-T for 5 min, repeat two times.

5. Incubate the sections with HRP-conjugated secondary antibody at appropriate dilution in antibody dilution buffer at room temperature in the dark for $1 \mathrm{~h}$.

6. Wash the sections with PBS-T for 5 min, repeat two times.

7. Incubate the sections in dark with HRP substrate solution.

8. Wash slides with PBS-T for 5 min, repeat two times to remove excess chromogen.

9. Dehydrate the slides with ascending graded alcohols (for $20 \mathrm{~s}$ each in 35,70 , and $95 \%$ ethanol, and $2 \mathrm{~min}$ in $100 \%$ ethanol) and clear in xylene.

10. Mount the slides with mounting medium.

\footnotetext{
${ }^{9}$ In case of incomplete antigen retrieval the duration of microwaving can be extended (timing needs to be adjusted by user as it depends on specimen preparation, thickness and fixation, and microwave power) or alternative methods like treatment of deparaffinized slides in a water bath or a steamer and enzymatic digestion can be applied. For a steamer or water bath, preheat glass jar filled with antigen retrieval buffer until boiling (temperature $>95^{\circ} \mathrm{C}$ ), insert slides and continue heating for $20-40$ min. Let glass jar cool to room temperature ( $20 \mathrm{~min})$. Wash sections twice in PBS-T for $5 \mathrm{~min}$ and continue with the staining procedure as described above. For enzymatic digestion of deparaffinized sections, transfer slides into a buffer containing $50 \mathrm{mM}$ Tris- $\mathrm{HCl}$, $\mathrm{pH} 8.0$, $5 \mathrm{mM}$ EDTA, and $10 \mu \mathrm{g} / \mathrm{ml}$ proteinase $\mathrm{K}$ and incubate at $37^{\circ} \mathrm{C}$ for $5 \mathrm{~min}$. Wash sections twice in PBS-T for 5 min and continue with the staining procedure as described above.

${ }^{10}$ To reduce nonspecific staining, BSA in both the "Blocking buffer" and the "Antibody dilution buffer" can be substituted with serum from the species in which the secondary antibody was raised (e.g., goat serum instead of BSA in the specified buffers when using AlexaFluor-594 goat anti-rabbit antibody). The use of detergents in the blocking buffer can be varied to improve antigen detection (e.g., up to $0.1 \%$ Triton X-100).
} 


\subsubsection{Immunofluores-cence Staining}

1. Incubate the sections in blocking buffer at room temperature for $30 \mathrm{~min}$ (see Note $10)$.

2. Incubate the sections with primary antibody at appropriate dilution (at least 1:200) in antibody dilution buffer in a humid-ified chamber for $1 \mathrm{~h}$ at room temperature or overnight at $4{ }^{\circ} \mathrm{C}$.

3. Wash the sections with PBS-T for 5 min, repeat two times.

4. Incubate the sections with fluorescent secondary antibody at appropriate dilution in antibody dilution buffer at room temperature in the dark for $1 \mathrm{~h}$ (see Note 11).

5. Wash the sections with PBS-T for 5 min, repeat two times.

6. Counterstain nuclei with DAPI in mounting medium (e.g., VECTASHIELD).

7. Coverslip and cure slides in the dark at room temperature for $4 \mathrm{~h}$ or at $4{ }^{\circ} \mathrm{C}$ overnight.

\subsubsection{Imaging of Immunofluorescence (See Note 12)}

1. Record immunofluorescence using appropriate filter for secondary antibody and for DAPI and record bright-field or DIC images.

2. Compare with sections developed without primary antibody to assess background fluorescence of tissue.

\subsection{Detection of Caspase-Specific Cleaved Products of PARP, Cytokeratin-18, and Lamin A in Tissue Homogenates and Tissue Sections as a Measure of Caspase Activation}

At present many target substrates of caspases have been identified in vitro and in vivo [27]. Proteins cleaved by caspases can be detected by western blot analysis using specific antibodies to the cleaved products produced by caspases. For example, cleavage of PARP, cytokeratin-18, and lamin A is commonly used as an indicator of apoptosis and activation of caspases. PARP is a nuclear DNA- binding protein and is involved in DNA base excision repair. PARP is a well-known substrate for caspase-3 in vitro and in vivo. Caspase-7 also cleaves PARP in vivo. Caspase-mediated cleavage of PARP produces two fragments of 85 and $24 \mathrm{kDa}[28,29]$, which can be detected by western blot using specific antibodies. Cytokeratin-18 (CK18), an important component of intermediate filaments in epithelial cells, is a target substrate of all of the executioner caspases, caspase- $3,-6$, and -7 [30, 31]. In response to an apoptotic stimulus, active executioner caspases cleave CK18 and a caspasegenerated neoepitope of CK18 at position Asp396 is selectively recognized by M30 monoclonal antibody (Roche Applied Sciences) by western blot or ELISA assay. Similarly, caspase activation results in a specific cleaved fragment of lamin A [32] that can be detected by western blot analysis. In response to an apoptotic stimulus, lamin $\mathrm{A} / \mathrm{C}$ is specifically

\footnotetext{
${ }^{11}$ Primary antibodies directly conjugated to a fluorescent reporter, such as FITC, can be more efficient in detection of the antigen. FITC-conjugated rabbit polyclonal anti-active cas-pase-3 antibody is available with Cell Signaling Technology Inc. The secondary antibody is not required after incubation of tissue section with fluorochrome-conjugated primary antibodies.

${ }^{12}$ Photobleaching is a common problem during immunofluorescence studies. This can be controlled by reducing the time-span or intensity of the light exposure. Photobleaching is generally less when efficient fluorophores such as Alexa Fluor are used.
} 
cleaved into a large (41-50 $\mathrm{kDa})$ and a small $(28 \mathrm{kDa})$ fragment particularly by active caspase-6 [33-35]. The caspase-6 recognition sequence VEID is present at amino acid residues $227-230$ in lamin $\mathrm{A} / \mathrm{C}$ protein.

1. Run western blots using specific antibodies to cleaved PARP, cytokeratin-18, or lamin A as outlined in Subheading 3.2.

2. Use the antibodies for immunohistochemistry as described in Subheading 3.3.

\section{Acknowledgments}

This work was supported by NIH grant R01 DK081690 and VA Merit Award to G.P.K. and VA Merit Award to R.S.H.

\section{References}

1. Hyman BT, Yuan J. Apoptotic and non-apoptotic roles of caspases in neuronal physiology and pathophysiology. Nat Rev Neurosci. 2012; 13:395-406. [PubMed: 22595785]

2. Kuranaga E. Beyond apoptosis: caspase regulatory mechanisms and functions in vivo. Genes Cells. 2012; 17:83-97. [PubMed: 22244258]

3. Yi CH, Yuan J. The Jekyll and Hyde functions of caspases. Dev Cell. 2009; 16:21-34. [PubMed: 19154716]

4. Kerr JF, Wyllie AH, Currie AR. Apoptosis: a basic biological phenomenon with wide-ranging implications in tissue kinetics. Br J Cancer. 1972; 26:239-257. [PubMed: 4561027]

5. Coleman ML, Sahai EA, Yeo M, et al. Membrane blebbing during apoptosis results from caspasemediated activation of ROCK I. Nat Cell Biol. 2001; 3:339-345. [PubMed: 11283606]

6. Faleiro L, Lazebnik Y. Caspases disrupt the nuclear-cytoplasmic barrier. J Cell Biol. 2000; 151:951-959. [PubMed: 11085998]

7. Luthi AU, Martin SJ. The CASBAH: a searchable database of caspase substrates. Cell Death Differ. 2007; 14:641-650. [PubMed: 17273173]

8. Taylor RC, Cullen SP, Martin SJ. Apoptosis: controlled demolition at the cellular level. Nat Rev Mol Cell Biol. 2008; 9:231-241. [PubMed: 18073771]

9. Darzynkiewicz Z, Pozarowski P, Lee BW, et al. Fluorochrome-labeled inhibitors of caspases: convenient in vitro and in vivo markers of apoptotic cells for cytometric analysis. Methods Mol Biol. 2011; 682:103-114. [PubMed: 21057924]

10. Tawa P, Tam J, Cassady R, et al. Quantitative analysis of fluorescent caspase substrate cleavage in intact cells and identification of novel inhibitors of apoptosis. Cell Death Differ. 2001; 8:30-37. [PubMed: 11313700]

11. Thornberry NA, Rano TA, Peterson EP, et al. A combinatorial approach defines specificities of members of the caspase family and granzyme B. Functional relationships established for key mediators of apoptosis. J Biol Chem. 1997; 272:17907-17911. [PubMed: 9218414]

12. Frances DE, Ingaramo PI, Mayoral R, et al. Cyclooxygenase-2 over-expression inhibits liver apoptosis induced by hyperglycemia. J Cell Biochem. 2013; 114:669-680. [PubMed: 23059845]

13. Kumar S, Allen DA, Kieswich JE, et al. Dexamethasone ameliorates renal ischemia-reperfusion injury. J Am Soc Nephrol. 2009; 20:2412-2425. [PubMed: 19797168]

14. Namura S, Zhu J, Fink K, et al. Activation and cleavage of caspase-3 in apoptosis induced by experimental cerebral ischemia. J Neurosci. 1998; 18:3659-3668. [PubMed: 9570797]

15. Lie ML, White LE, Santora RJ, et al. Lung T lymphocyte trafficking and activation during ischemic acute kidney injury. J Immunol. 2012; 189:2843-2851. [PubMed: 22888136]

16. Yin XM, Luo Y, Cao G, et al. Bid-mediated mitochondrial pathway is critical to ischemic neuronal apoptosis and focal cerebral ischemia. J Biol Chem. 2002; 277:42074-42081. [PubMed: 12200426] 
17. Condorelli G, Roncarati R, Ross J Jr, et al. Heart-targeted overexpression of caspase 3 in mice increases infarct size and depresses cardiac function. Proc Natl Acad Sci U S A. 2001; 98:99779982. [PubMed: 11493678]

18. Chen J, Wang W, Zhang Q, et al. Low molecular weight fucoidan against renal ischemiareperfusion injury via inhibition of the MAPK signaling pathway. PLoS One. 2013; 8:e56224. [PubMed: 23418539]

19. Duan WR, Garner DS, Williams SD, et al. Comparison of immunohistochemistry for activated caspase-3 and cleaved cytokeratin 18 with the TUNEL method for quantification of apoptosis in histological sections of PC-3 subcutaneous xenografts. J Pathol. 2003; 199:221-228. [PubMed: 12533835]

20. Hughes J, Gobe G. Identification and quantification of apoptosis in the kidney using morphology, biochemical and molecular markers. Nephrology (Carlton). 2007; 12:452-458. [PubMed: 17803468]

21. Jakob S, Corazza N, Diamantis E, et al. Detection of apoptosis in vivo using antibodies against caspase-induced neo-epitopes. Methods. 2008; 44:255-261. [PubMed: 18314057]

22. Ohsawa S, Hamada S, Yoshida H, et al. Caspase-mediated changes in histone H1 in early apoptosis: prolonged caspase activation in developing olfactory sensory neurons. Cell Death Differ. 2008; 15:1429-1439. [PubMed: 18483489]

23. Canbay A, Feldstein A, Baskin-Bey E, et al. The caspase inhibitor IDN-6556 attenuates hepatic injury and fibrosis in the bile duct ligated mouse. J Pharmacol Exp Ther. 2004; 308:1191-1196. [PubMed: 14617689]

24. Li J, Li Y, Ogle M, et al. DL-3-n- butylphthalide prevents neuronal cell death after focal cerebral ischemia in mice via the JNK pathway. Brain Res. 2010; 1359:216-226. [PubMed: 20800583]

25. You Z, Savitz SI, Yang J, et al. Necrostatin-1 reduces histopathology and improves functional outcome after controlled cortical impact in mice. J Cereb Blood Flow Metab. 2008; 28:1564-1573. [PubMed: 18493258]

26. Zhang X, Chen W, De Paiva CS, et al. Interferon-gamma exacerbates dry eye-induced apoptosis in conjunctiva through dual apoptotic pathways. Invest Ophthalmol Vis Sci. 2011; 52:6279-6285. [PubMed: 21474767]

27. Timmer JC, Salvesen GS. Caspase substrates. Cell Death Differ. 2007; 14:66-72. [PubMed: 17082814]

28. Lazebnik YA, Kaufmann SH, Desnoyers S, et al. Cleavage of poly(ADP-ribose) poly-merase by a proteinase with properties like ICE. Nature. 1994; 371:346-347. [PubMed: 8090205]

29. Tewari M, Quan LT, O'Rourke K, et al. Yama/CPP32 beta, a mammalian homolog of CED-3, is a CrmA-inhibitable protease that cleaves the death substrate poly(ADP-ribose) polymerase. Cell. 1995; 81:801-809. [PubMed: 7774019]

30. Caulin C, Salvesen GS, Oshima RG. Caspase cleavage of keratin 18 and reorganization of intermediate filaments during epithelial cell apoptosis. J Cell Biol. 1997; 138:1379-1394. [PubMed: 9298992]

31. Leers MP, Kolgen W, Bjorklund V, et al. Immunocytochemical detection and mapping of a cytokeratin 18 neo-epitope exposed during early apoptosis. J Pathol. 1999; 187:567-572. [PubMed: 10398123]

32. Mintzer R, Ramaswamy S, Shah K, et al. A whole cell assay to measure caspase-6 activity by detecting cleavage of lamin A/C. PLoS One. 2012; 7:e30376. [PubMed: 22253931]

33. Okinaga T, Kasai H, Tsujisawa T, et al. Role of caspases in cleavage of lamin A/C and PARP during apoptosis in macrophages infected with a periodontopathic bacterium. J Med Microbiol. 2007; 56:1399-1404. [PubMed: 17893180]

34. Orth K, Chinnaiyan AM, Garg M, et al. The CED-3/ICE-like protease Mch2 is activated during apoptosis and cleaves the death substrate lamin A. J Biol Chem. 1996; 271:16443-16446. [PubMed: 8663580]

35. Ruchaud S, Korfali N, Villa P, et al. Caspase-6 gene disruption reveals a requirement for lamin A cleavage in apoptotic chromatin condensation. EMBO J. 2002; 21:1967-1977. [PubMed: 11953316] 
36. McStay GP, Salvesen GS, Green DR. Overlapping cleavage motif selectivity of caspases: implications for analysis of apoptotic pathways. Cell Death Differ. 2008; 15:322-331. [PubMed: 17975551]

37. Altieri DC. Survivin and IAP proteins in cell-death mechanisms. Biochem J. 2010; 430:199-205. [PubMed: 20704571] 